P2032

\title{
職域における2型糖尿病発症予防研究（第一報） 一参加者背景に関する検討-
}

根本 浩一郎 ${ }^{1}$ 、千葉 陽子 ${ }^{1}$ 、大野 秀樹 ${ }^{3}$ 、高橋 英孝 ${ }^{2}$ 、中館 俊夫 ${ }^{2}$

${ }^{1}$ 横浜郵政健康管理センター、 ${ }^{2}$ 昭和大学医学部衛生学教室、 ${ }^{3}$ 杏林大学医学部衛生学・公衆衛生学

【目的】IGT と判定された職員に対して積極的な生活 指導を 3 年間に渡り継続することにより、糖尿病発 症予防のシステム作りを構築中である。初年度の検 討を報告する。

【方法】 初年度として、神奈川県内某公社を対象に適 格と考えられ文書にて同意を得た職員に糖負荷試験 (採血は糖負荷前、負荷後 30 分、負荷後 120 分)を 2004 年 3 月に施行し、日本糖尿病学会基準と WHO 基準 に従いIGT 群を抽出し、血液生化学検查と身体計测、 生活背景調查、運動量調查 (スズケン e-style を使用)、 ストレス調查（下光らによる職業性ストレス簡易調 查票を使用）を実施した。次に IGT 群の中から metabolic syndrome 群 (以下 MS 群) 16 人と non-MS 群 10 人を抽出し各群の臨床的特徴と環境因子の異 同を検討した。MS の基準は腹囲 $\geqq 85 \mathrm{~cm}$ （女性は $90 \mathrm{~cm}) 、 \mathrm{SBP} \geqq 130 \mathrm{mmHgorDBP} \geqq 85 \mathrm{mmHg} 、 \mathrm{TG} \geqq$ $150 \mathrm{mg} / \mathrm{dl} 、 \mathrm{HDL}-\mathrm{C}<40 \mathrm{mg} / \mathrm{dl}$ （女性は $50 \mathrm{mg} / \mathrm{dl}$ ）の 4 項目中 2 項目以上を満たす人とした。統計学的解 析はStatMate3を用いた。各解析に扔いて危険率 (以 下 $P$ と省略）5\%以下を有意とした。

[結果】1)IGT 抽出について:定期健診で IGT が疑わ れた職員約 720 人（年龄は 25-59 歳）に参加を呼び かけ、199 人に糖負荷試験を施行した。IGT 群は 41 人(糖負荷武験施行者の 20.6\%)であった。

2)IGT 群の全体像について:検討した 28 人中、内勤 者 12 人、外勤者 16 人、夜勤をする人 6 人、重量物 取り扱い者 3 人であった。血液検查結果を Tablelに 示した。

3)MS 群と non-MS 群(以下 2 群)の臨床的特徴と環 境因子の検討:3-1） NCEP-ATP3 に採用されている 5 つの代謝異常因子保有者数（Table2）と I(インスリ ン分泌指数）低下者（II<0.4）を 2 群で検討した。
Iに注目すると non-MS 群では全員低下していたが、 MS 群では低下者は約 $1 / 3$ に過ぎず $(\mathrm{P}<0.05)$ 、両群は 別の病態を示す集団と考えた。3-2)食習慣に関する 2 項目、歩行に関する 3 項目、ストレス調查に関する 3 項目、睡眠時間について両群間で有意差のあった 項目は歩行数であった $(\mathrm{P}<0.05)$ 。

[考察·結論] 6 ケ月後の糖負荷試験を実施した結果、 糖尿病型に移行した 4 人はいずれもMS と考えられ、 IGT 集団から MS を同定することは意義があると考 える。今後の前向き介入研究において MS の糖尿病 発症予測因子としての意義を検討していきたい。

\begin{tabular}{|c|c|c|}
\hline & 平均 & 掼䔓傐差 \\
\hline 対象者（男性／女性） & $41(35 / 6)$ & \\
\hline 年答 (才) & 48 & 8 \\
\hline 空腹時血精 $(\mathrm{mg} / \mathrm{dl})$ & 106 & 12 \\
\hline 血藉 30 分值 $(\mathrm{mg} / \mathrm{dl})$ & 189 & 33 \\
\hline 血糖2時間优 $(\mathrm{mg} / \mathrm{dl})$ & 163 & 16 \\
\hline F-IRI $(\mu \mathrm{U} / \mathrm{d} \mid)$ & 6.8 & 4.5 \\
\hline IRI-30 $(\mu \mathrm{U} / \mathrm{mI})$ & 36.2 & $(2.1-209)$ \\
\hline IRI-120 $(\mu \mathrm{U} / \mathrm{mI})$ & 81.4 & $(14.4-573)$ \\
\hline II & 0.4 & 0.29 \\
\hline HOMA-R & 1.8 & 1.1 \\
\hline $\mathrm{TC}(\mathrm{mg} / \mathrm{dl})$ & 212 & 39 \\
\hline $\mathrm{TG}(\mathrm{mg} / \mathrm{dl})$ & 117 & 62 \\
\hline $\mathrm{HDL}-\mathrm{C}(\mathrm{mg} / \mathrm{dl})$ & 57 & 14 \\
\hline $\mathrm{LDL}-\mathrm{C}(\mathrm{mg} / \mathrm{dl})$ & 136 & 34 \\
\hline $\mathrm{UA}(\mathrm{mg} / \mathrm{dl})$ & 6.3 & 1 \\
\hline adiponectin & 6.3 & 1 \\
\hline hs-CRP & 0.7 & $(0.1-4.7)$ \\
\hline
\end{tabular}

Table2 2群的ての代的買常因子保有者数比䧶

\begin{tabular}{|c|c|c|}
\hline & MS静 & non-MS棌 \\
\hline 做部肥满 & 100 & 10 \\
\hline SBP京位 & 93.5 & 20 \\
\hline DBP京任 & 62.5 & 0 \\
\hline 血TG & 43.8 & \\
\hline 低HDL-C & 12.5 & 10 \\
\hline 眪FPG & 50 & 10 \\
\hline 高BMI & 68.9 & 0 \\
\hline
\end{tabular}

